\title{
Membangun Pemahaman Bacaan Mahasiswa melalui Aktivitas Pascabaca
}

\section{Building Reading Comprehension in College Students through Post-Reading Activities}

\author{
Indah Pujiastuti ${ }^{1, *}$, Vismaia S. Damaianti ${ }^{2}$, dan Syihabuddin ${ }^{3}$ \\ 1,2,3 Universitas Pendidikan Indonesia \\ 1 Universitas Maritim Raja Ali Haji \\ 1," Email: indah.pujiastuti@upi.edu; Orcid: https://orcid.org/0000-0003-0327-3701 \\ 2 Email: vismaia@upi.edu; Orcid: https://orcid.org/0000-0002-2660-5628 \\ 3 Email: syhihabuddin@upi.edu; Orcid: https://orcid.org/0000-0003-4403-4803
}

\begin{abstract}
ARTICLE HISTORY
Received 12 December 2021

Accepted 4 January 2022

Published 1 February 2022

KEYWORDS

post-reading, reading comprehension, critical reading, mindset.

KATA KUNCI

pascabaca, membaca pemahaman, membaca kritis, pola pikir.

ABSTRACT

Activity after reading (post-reading) is the stage where a reader responds to what he has read. At this stage, it is hoped that there will be changes from readers, changes in mindset, understanding, and increasing knowledge. This study describes the implementation of activities after reading carried out by students independently and structured. This research is a descriptive survey. Data were obtained from questionnaires distributed to 246 students and 11 lecturers of the Indonesian Language and Literature Education Departments, Raja Ali Haji Maritime University. The findings are, first, the majority of students read fiction when reading independently. After reading, students carry out various activities such as recording quotes, summarizing readings, recording difficult vocabulary, and discussing. Second, when reading in a structured way, students read a lot of non-fiction, such as reference books, scientific articles, research reports, handouts. Activities carried out after structured reading are writing activities such as summarizing, compiling presentation materials, writing reports, and writing reviews. However, students' have obstacles when completing activities after reading, such as difficulty in concluding readings, understanding sentences, and reading vocabulary there that the expected results after reading are not optimal. These obstacles cause students to only rewrite (copy-paste) readings. Students have not yet reached the stage of how critical reading and building their mindset.

\section{ABSTRAK}

Aktivitas setelah membaca (pascabaca) merupakan tahap seorang pembaca memberikan respons pada apa yang telah dibacanya. Pada tahap ini, diharapkan adanya perubahan dari pembaca, perubahan pola pikir, pemahaman, dan bertambahnya pengetahuan. Penelitian ini bertujuan untuk mendeskripsikan pelaksanaan kegiatan setelah membaca yang dilakukan oleh mahasiswa secara mandiri dan terstruktur. Penelitian ini adalah survei deskriptif. Data diperoleh dari angket yang dibagikan kepada 246 mahasiswa dan 11 dosen Program Studi Pendidikan Bahasa dan Sastra Indonesia, Universitas Maritim Raja Ali haji. Hasil temuannya, pertama, mayoritas mahasiswa membaca bacaan fiksi ketika membaca secara mandiri. Setelah membaca, mahasiswa melakukan aktivitas beragam seperti mencatat kutipan menarik (quotes), meringkas bacaan, menulis kosakata yang sulit, dan mendiskusikan bacaan. Kedua, ketika membaca secara terstruktur mahasiswa banyak membaca bacaan nonfiksi, seperti buku referensi, artikel ilmiah, laporan penelitian, dan handout. Aktivitas yang dilakukan setelah membaca terstruktur adalah kegiatan menulis seperti meringkas, menyusun bahan presentasi, menulis laporan, dan menulis resensi. Namun, mahasiswa memiliki hambatan ketika menyelesaikan aktivitas setelah membaca, seperti kesulitan dalam menyimpulkan bacaan; memahami kalimat dan kosakata bacaan sehingga hasil yang diharapkan setelah membaca tidak maksimal. Hambatan tersebut menyebabkan mahasiswa hanya menulis ulang bacaan. Mahasiswa belum sampai pada tahapan bagaimana mengkritisi sebuah bacaan dan membangun pola pikirnya.
\end{abstract}

To cite this article:

Pujiastuti, I., Damaianti, V. S., \& Syihabuddin, S. (2022). Membangun Pemahaman Bacaan Mahasiswa melalui Aktivitas Pascabaca. Diglosia: Jurnal Kajian Bahasa, Sastra, dan Pengajarannya, 5(1), 119-134. https://doi.org/10.30872/diglosia.v5i1.356 


\section{A. Pendahuluan}

Aktivitas membaca merupakan kemahiran yang fundamental pada tingkatan perguruan tinggi (Hurst, 2011; Arifin, 2020; Ari, 2017). Keberhasilan mahasiswa di tingkat universitas tergantung pada tingkat keterampilan akademiknya, satu di antaranya adalah kemahiran membaca (Hermida, 2009; Arifin, 2020; (NoblesMontanez \& Cruz, 2020). Lebih lanjut, (Septhin et al., 2018; Wahyono \& Puspitasari, 2016) membaca adalah suatu kegiatan untuk memenuhi harapan peserta didik untuk kebutuhan akademik. Membaca menjadi dasar dalam menulis dan meneliti di perguruan tinggi (Hurst, 2011). Dengan membaca, keterampilan memecahkan masalah (problem solving) juga dapat diperkuat (Ari, 2017).

Kegiatan membaca pada tingkatan perguruan tinggi harus mencakup pemahaman yang tinggi, refleksi serta interpretasi yang lebih luas oleh pembacanya (Huang et al., 2014). Aktivitas membaca tidak bisa hanya sekadar untuk memahami arti kata secara etimologis atau mendapatkan pengetahuan faktual saja. Membaca harus melibatkan keterampilan berpikir tingkat tinggi mulai dari analisis hingga evaluasi untuk memberikan pertimbangan-pertimbangan terhadap teks yang dibaca (Priyatni \& Nurhadi, 2017). Aktivitas membaca membutuhkan kemampuan otak untuk memproses makna dari penulis dan membangun respons pembaca (Setyaningtyas, 2013).

Pembaca yang baik cenderung menggunakan berbagai strategi saat membaca seperti membuat prediksi sebelum membaca, membuat koneksi ke pengalaman dan pengetahuan pribadi, dan terlibat dalam pemantauan diri (ongoing) pemeriksaan pemahaman teks (Hasibuan, 2015). Pembaca yang baik terus memantau pemahaman mereka tentang teks saat mereka membacanya. Mereka memprediksi, mempertanyakan, mengklarifikasi, meringkas, menghubungkan, dan mengevaluasi saat mereka membaca (Schoenback, 1999). Pembaca tersebut dapat berdialog dengan penulis dan diri mereka sendiri.

Strategi membaca tersebut biasa diterapkan dalam tiga tahapan, yaitu aktivitas sebelum membaca (prabaca), selama membaca, dan setelah membaca (pascabaca) (Arcos, 2014; Hamidon et al., 2013; Gibbons, 2015). Prabaca berfungsi untuk membangkitkan motivasi, skemata pembaca, dan menghubungkan pengetahuan awal membaca (Herlinyanto, 2019; Roe et al., 2019). Tahapan selama membaca berfungsi menyeleksi dan mengorganisasikan (Herlinyanto, 2019; Rehman et al., 2020). Aktivitas selama membaca ada dua hal yang terlibat, yaitu strategi membaca kognitif dan membaca meta kognitif (Rehman et al., 2020; Roe et al., 2019). Tahapan setelah membaca bertujuan untuk memastikan pemahaman pembaca dan retensi informasi dari teks yang telah mereka baca (Hamidon et al., 2013).

Menjadi pembaca yang baik artinya pembaca mampu melaksanakan peran pembaca dalam aktivitas prabaca, selama membaca, dan pascabacanya. Freebody \& Luke (1990) menyarankan bahwa ada empat komponen keberhasilan membaca dan bahwa pembaca yang sukses membutuhkan sumber daya untuk mengambil keempat peran tersebut saat mereka membaca. Peran 
tersebut adalah code-breaker, text participant, text user, dan text analysis.Codebreaker (pemecah teks), yaitu kegiatan memahami, membedakan, dan menyatukan kode atau simbol menjadi ujaran yang bermakna; text participant (pembuat makna), usaha untuk memahami teks dengan menghubungkan pengetahuan awal dan lata belakang sosial, budaya pembaca; text-user (pengguna teks) memahami membaca teks dilihat dari konteks sosial dan tujuan menggunakan teks dengan cara yang berbeda-beda sesuai dengan fungsi sosial dan budaya pembaca; dan text analysis (penganalisis teks) pembaca dapat memberikan kritik atau penilaian terhadap teks tersebut (Freebody \& Luke, 1990; Gibbons, 2015; Ratminingsih, 2017).

Masing-masing dari empat peran ini menekankan aspek tertentu dari membaca dan semuanya merupakan bagian integral dari membaca yang efektif (Gibbons, 2015). Empat peran pembaca tersebut terlibat dalam strategi prabaca, selama membaca, dan pascabaca (Setianingsih, 2016) karena empat peran ini membawa pembaca pada tingkat berpikir lebih tinggi dan pemahaman bacaan yang lebih baik sehingga menjadi pembaca yang berhasil (Setyaningtyas, 2013).

Akan tetapi, aktivitas pascabaca kadang terabaikan oleh pengajar di perguruan tinggi (Hamidon et al., 2013). Rencana pelajaran dengan kegiatan pramembaca yang baik dan kegiatan selama membaca terencana dengan baik, tetapi kegiatan pasca-membaca yang singkat dan klasik, "ala kadarnya" (Wahjudi, 2010). Padahal tahapan pascabaca menjadi sangat penting karena membantu pembaca menggunakan pengetahuan yang diperoleh dari bahan bacaan untuk diintegrasikan dengan keterampilan bahasa lain seperti menyimak, berbicara dan menulis (Rehman et al., 2020).

Menurut Singer \& Wong yang dikutip oleh Han \& Choi (2018) tahap pascabaca berfungsi sebagai tahap bagi pembelajar bahasa untuk menginternalisasi secara mendalam apa yang mereka baca dan meningkatkan kemampuan pemahaman bacaan; mereka juga bisa berhenti untuk menilai apakah informasi yang dibaca penting dan memantau keadaan mereka sendiri pemahaman bacaan. Informasi baru yang diperoleh pada fase selama membaca dapat menghasilkan perubahan yang dilihat setelah membaca, misalnya, pembaca memiliki pengetahuan lebih, atau berpikir dan merasa beda dari sebelumnya (Wahjudi, 2010).

Beberapa penelitian menganggap bahwa lulusan sebuah perguruan tinggi belum tentu pembaca yang baik meskipun mereka membaca materi akademik tingkat lanjut karena tidak selalu memahami informasi yang dibacanya (Arcos, 2014) karena mahasiswa hanya sekadar membaca tanpa melakukan aktivitas setelah membaca. Hasil penelitian Hoeft (2012) juga menunjukkan 46\% mahasiswanya melaporkan bahwa mereka melakukan aktivitas membaca seperti yang diinstruksikan, namun hanya 55\% dari mahasiswa tersebut yang dapat menunjukkan tingkat pemahaman paling dasar dari materi yang mereka "klaim" telah dibaca. Penelitian Andina (2017) juga menjelaskan kegiatan membaca di perguruan tinggi hanya sekadar kewajiban untuk menghadapi ujian sehingga pengetahuan yang diperoleh hanya hasil hafalan yang akan segera hilang ketika isi bacaan tidak diperlukan lagi. Akibatnya tidak semua mahasiswa mampu menjadi pembaca yang baik (Arcos, 2014). 
Pernyataan di atas didukung juga data World Bank (2018), "55\% orang Indonesia yang sudah menyelesaikan pendidikan buta huruf secara "fungsional". Buta huruf secara fungsional artinya penduduk Indonesia bisa "membaca teks" tetapi tidak mampu menjawab pertanyaan yang berkaitan dengan teks tersebut. Ini menegaskan pendapat Suwandi (2019) bahwa semua peserta didik terutama mahasiswa dapat membaca, tetapi mereka tidak terbiasa untuk menjadikan kegiatan membaca sebagai akses untuk memperoleh informasi dan pengetahuan. Ini artinya kemampuan untuk membaca tidak berarti apa-apa jika individu yang melek huruf tidak dapat memecahkan kode makna teks (Wells, 2012) bahkan untuk mahasiswa sekalipun. Kemampuan membaca tidak akan berguna (Satriani, 2018), ketika pembaca tidak memahami apa pun, tidak ada refleksi atau perubahan dari dirinya.

Didorong dari fenomena dan latar belakang di atas, penelitian ini bertujuan untuk mendeskripsikan pelaksanaan kegiatan pascabaca yang telah dilakukan mahasiswa di selama perkuliahan. Untuk mencapai tujuan tersebut, penulis melakukan kajian menggunakan teori tahapan aktivitas membaca (pra-reading, during reading, and after reading). Diharapkan penelitian ini dapat menjadikan gambaran untuk melaksanakan kegiatan membaca ke depannya.

\section{B. Metode}

Penelitian ini berbentuk penelitian survei deskriptif (descriptive survey). Penelitian deskriptif bertujuan untuk menjelaskan, mencatat suatu kondisi sosial tertentu dan sikap tertentu (Morissan, 2012). Berdasarkan pernyataan tersebut, penelitian ini bertujuan untuk menafsirkan secara rinci dan mencatat aktivitas membaca mahasiswa berupa aktivitas pascabaca mahasiswa Program Studi Pendidikan Bahasa dan Sastra Indonesia (PBSI), Fakultas Keguruan dan IImu Pendidikan (FKIP), Universitas Maritim Raja Ali Haji (UMRAH), yang datanya diperoleh dari kuesioner/angket.

Dilihat dari sudut pandangnya, kuesioner dibedakan dalam tiga jenis, yaitu pertanyaan terbuka (kuesioner tidak terstruktur), pertanyaan tertutup (kuesioner terstruktur), dan pertanyaan tertutup dan terbuka (kombinasi) (Nasehudin \& Gozali, 2012). Pada penelitian ini, angket yang digunakan adalah angket dengan pertanyaan tertutup dan terbuka sehingga dapat memberikan kesempatan kepada responden memilih jawaban yang telah tersedia atau membuatnya sendiri.

Data diperoleh dari dua sumber. Sumber pertama adalah mahasiswa. Mahasiswa yang menjadi populasi dalam penelitian ini adalah mahasiswa aktif di program studi PBSI yang mengikuti perkuliahan semester 1, 3, 5, dan 7. Populasi tersebut berjumlah 339 mahasiswa dan sampel didapatkan secara acak berjumlah 246 mahasiswa. Daftar pertanyaan yang diberikan menggambarkan tentang keadaan responden sendiri, angket ini disebut angket langsung (Widoyoko, 2012). 
Tabel 1. Kisi-Kisi Instrumen Aktivitas Setelah Membaca

\begin{tabular}{|c|c|c|}
\hline No. & Variabel & Indikator \\
\hline A. & Daftar Pertanyaan untuk Mahasiswa & \\
\hline 1. & $\begin{array}{l}\text { Aktivitas Membaca secara Mandiri oleh } \\
\text { Mahasiswa }\end{array}$ & $\begin{array}{ll}\text { a. Jenis bacaan } \\
\text { b. }\end{array}$ \\
\hline 2. & Aktivitas Membaca selama Perkuliahan & $\begin{array}{l}\text { a. Jenis bacaan } \\
\text { b. Aktivitas pascabaca } \\
\text { c. Kesulitan dalam mengerjakan tugas } \\
\text { membaca } \\
\text { d. Kesulitan dalam membaca teks nonfiksi }\end{array}$ \\
\hline B. & Daftar Pertanyaan untuk Dosen & \\
\hline 1. & Persepsi Dosen & $\begin{array}{l}\text { a. Tingkat kepuasan dosen } \\
\text { b. Alasan kepuasan dosen } \\
\text { c. Alasan ketidakpuasan dosen } \\
\text { d. Kendala mahasiswa dalam membaca }\end{array}$ \\
\hline
\end{tabular}

Sumber kedua adalah dosen tetap (homebase) PBSI, UMRAH yang berjumlah 11 orang. Dosen memberikan respons terhadap keadaan mahasiswa yang melakukan aktivitas membaca. Angket yang dibagikan kepada dosen ini disebut angket tidak langsung (Widoyoko, 2012). Daftar pertanyaan yang diberikan kepada mahasiswa dan dosen dituliskan di google form. Tautannya google form tersebut dibagikan melalui whatsapp. Daftar pertanyaan yang diberikan kepada kedua sumber dapat dilihat pada Tabel 1.

Teknik analisis data berupa statistik deskriptif. Langkah menganalisis data sebagai berikut. Pertama, data dikelola dalam suatu tabel tunggal, yaitu tabel nilai yang disusun berdasarkan indikator pertanyaan. Kedua, data tersebut diolah dalam bentuk persentase yang kemudian dideskripsikan. Ketiga, selanjutnya menyimpulkan teori-teori yang ada dengan data empiris.

\section{Pembahasan}

Kegiatan membaca yang dilakukan oleh mahasiswa terdiri dari dua aktivitas. Pertama, kegiatan membaca secara mandiri oleh mahasiswa dan kedua, kegiatan membaca karena penugasan yang diberikan oleh dosen. Penjabarannya sebagai berikut.

\section{Aktivitas Membaca secara Mandiri}

Kegiatan membaca mandiri (independent reading) adalah kebebasan membaca dengan materi yang dipilih (Faizah et al., 2016; Handayani, 2019; Sanden, 2011). Mahasiswa secara sengaja menyediakan waktu untuk membaca secara mandiri (Sanden, 2011). Aktivitas ini menjadi penting karena aktivitas membaca mandiri dalam meningkatkan kemampuan membaca seseorang (Horne, 2014; Sanden, 2011). Bagaimanapun kegiatan pembelajaran secara mandiri dituntut dalam proses perkuliahan (Taglieber, 2000). Ada dua pertanyaan yang diajukan untuk indikator ini. Pertanyaan pertama adalah jenis bacaan disukai mahasiswa ketika membaca mandiri. Kedua adalah aktivitas yang dilakukan mahasiswa setelah membaca. Hasilnya adalah sebagai berikut. 


\section{a. Jenis Bacaan}

Ketika mahasiswa membaca secara mandiri, jenis bacaan yang lebih disukai berupa teks fiksi. Hal ini dibuktikan dari hasil survei bahwa empat urutan teratas adalah teks fiksi, yaitu novel, cerpen, komik, dan puisi. Hasilnya dirangkum pada Tabel 2. Berdasarkan Tabel 2, jenis bacaan pada urutan nomor 9-12 merupakan bahan bacaan yang ditambahkan oleh responden sendiri berupa pantun, teks sejarah, quotes dan alternate universe. Yang menarik adalah Quotes dan Alternative Universe. Kedua teks tersebut menjadi tren seiring dengan berkembangnya media sosial (Haapanen \& Perrin, 2017). Quotes biasanya digunakan sebagai caption atau teks singkat untuk menceritakan keadaan seseorang di media sosial lebih andal dan estetik (Sociality.io, n.d.). Alternative Universe atau $A U$ merupakan cerita yang biasa ditemukan di Twitter dalam bentuk utas (thread) dengan mengandalkan jumlah karakter yang terbatas yang dibuat oleh penggemar (fanfiction). Cerita berkisar tentang idola setiap penggemar dan penggemar bisa terlibat dalam cerita tersebut (Anjani, 2021).

\section{b. Aktivitas Pascabaca}

Setelah membaca secara mandiri, ada beberapa aktivitas yang dilakukan oleh mahasiswa. Aktivitas tersebut diurutkan dari yang sering dilakukan hingga jarang dilakukan. Aktivitas tersebut dapat dilihat pada Tabel 3. Berdasarkan Tabel 3 diketahui bahwa mahasiswa melakukan beragam aktivitas setelah membaca. Diketahui lebih dari 50\% sampel mencatat kutipan menarik dari sebuah tulisan, kemudian diikuti kegiatan meringkas, mencatat kosakata yang sulit, dan berdiskusi. Selain itu, aktivitas lainnya dilakukan oleh kurang dari 10 mahasiswa, seperti menerapkannya dalam kehidupan, menyimpulkan, mendiskusikan dan merekomendasikannya, dan membeli buku (jika buku tersebut menarik). Hanya 1 mahasiswa $(0,40 \%)$ yang terkadang membuat ringkasan dan 3 mahasiswa $(1,21 \%)$ tidak melakukan aktivitas apa pun setelah membaca.

\section{Tabel 2. Urutan Bahan Bacaan yang Disukai}

\begin{tabular}{clcc}
\hline No. & Bahan Bacaan & Jumlah Mahasiswa & Persentase \\
\hline 1. & Novel & 186 & $75,30 \%$ \\
2. & Cerpen & 166 & $67,21 \%$ \\
3. & Komik & 119 & $48,18 \%$ \\
4. & Puisi & 99 & $40,08 \%$ \\
5. & Artikel & 91 & $36,84 \%$ \\
6. & Buku Nonfiksi & 86 & $34,81 \%$ \\
7. & Berita & 72 & $29,14 \%$ \\
8. & Fiksi Penggemar (Fanfiction) & 49 & $19,84 \%$ \\
9. & Pantun & 2 & $0,81 \%$ \\
10. & Teks Sejarah & 1 & $0,4 \%$ \\
11. & Quotes & 1 & $0,4 \%$ \\
12. & Alternate Universe & 1 & $0,4 \%$ \\
\hline
\end{tabular}


Tabel 3. Aktivitas Setelah Membaca

\begin{tabular}{clcc}
\hline No. & Aktivitas & Jumlah Mahasiswa & Persentase \\
\hline 1. & Mencatat kutipan menarik dari bacaan (quote) & 130 & $52,63 \%$ \\
2. & Meringkas & 117 & $47,37 \%$ \\
3. & Mencatat kosakata yang sulit & 81 & $32,79 \%$ \\
4. & Mendiskusikan dengan teman & 59 & $23,89 \%$ \\
5. & Menerapkan dalam kehidupan & 4 & $1,62 \%$ \\
6. & Mengingat poin penting & 3 & $1,21 \%$ \\
7. & Tidak melakukan apa-apa & 3 & $1,21 \%$ \\
8. & Menyimpulkan & 2 & $0,81 \%$ \\
9. & Kadang meringkas kadang tidak & 1 & $0,40 \%$ \\
10. & Mendiskusikan dan merekomendasikannya & 1 & $0,40 \%$ \\
11. & Membeli bukunya & 1 & $0,40 \%$ \\
\hline
\end{tabular}

\section{Aktivitas Membaca Selama Perkuliahan}

Selama mengikuti perkuliahan di Program Studi Pendidikan Bahasa dan Sastra Indonesia, membaca menjadi aktivitas penting yang dilakukan mahasiswa. Aktivitas membaca biasanya juga menjadi salah satu penilaian untuk mahasiswa. Mahasiswa diminta untuk membaca berbagai jenis bahan bacaan. Sebanyak 211 mahasiswa atau 86,12\% menjawab bahwa buku nonfiksi menjadi bahan bacaan utama ketika diberikan tugas membaca. Berbeda dari kegiatan yang dilakukan oleh mahasiswa secara mandiri, 6 urutan teratas jenis bacaan yang dibaca oleh mahasiswa adalah teks-teks nonfiksi, selain itu materi (handout) dari dosen menjadi salah satu jenis bacaan yang banyak dibaca oleh mahasiswa. Urutan bahan bacaan pada aktivitas membaca selama perkuliahan dapat dilihat pada Tabel 4.

\section{a. Aktivitas Setelah Membaca}

Kegiatan setelah membaca bahan bacaan yang merupakan tagihan tugas dalam membaca dirangkum pada Tabel 5. Ada beragam aktivitas setelah membaca selama perkuliahan jika dilihat dari Tabel 5. Aktivitas membaca didominasi dengan kegiatan menyusun ringkasan. Kegiatan selanjutnya menyusun bahan presentasi yang biasanya merupakan ringkasan dari membaca yang kemudian dipresentasikan dan didiskusikan di kelas. Selanjutnya ada kegiatan menceritakan ulang, menyusun laporan analisis bacaan, menulis resensi, menulis laporan buku, menyunting karangan.

\section{b. Kesulitan dalam Mengerjakan Tugas Membaca}

Dibandingkan kegiatan mandiri yang dilakukan mahasiswa, kegiatan membaca yang merupakan penugasan oleh mahasiswa memiliki kesulitan tersendiri. Hal ini disebabkan bahan bacaan ditentukan oleh dosen dan sudah memiliki instruksi yang jelas pada setiap tahapan kegiatan. Kesulitan tersebut secara umum dijelaskan dalam Tabel 6.

Tidak memiliki bahan bacaan yang dimaksud menjadi penyebab utama, mahasiswa kesulitan dalam melakukan aktivitas membaca. Selain tidak memiliki bacaan secara pribadi, mahasiswa juga kesulitan untuk memperolehnya di 
perpustakaan seperti ditunjukkan dalam pernyataan ketiga. Hal ini senada dengan pernyataan Kepala Perpustakaan Nasional (Perpusnas) Muhammad Syarif Bando bahwa rasio ketersediaan buku dan jumlah penduduk adalah 0,09 yang artinya 1 buku ditunggu 90 orang (Waspada, 2021).

Faktor penghambat selanjutnya adalah faktor penghambat yang muncul dari mahasiswa. Kemampuan yang kurang dalam menyimpulkan isi bacaan, kesulitan dalam memahami kosakata dalam bacaan, tidak memahami tugas, bahkan 19 mahasiswa yang menjadi responden mengaku malas dan tidak berminat membaca. Hal ini bisa disebabkan karena bacaan yang ditugaskan bukan buku yang disukai mahasiswa. Walaupun begitu, dari 246 mahasiswa, 5 di antaranya tidak memiliki kesulitan dalam mengerjakan tugas membaca dari dosen.

\section{c. Kesulitan Mahasiswa dalam Membaca Teks Ragam IImiah}

Secara khusus, mahasiswa diberikan pertanyaan tentang kesulitan dalam membaca teks ragam ilmiah. Teks-teks ini biasanya mendukung aktivitas membaca akademik mahasiswa. Jika dilihat dari Tabel 7, kesulitan mahasiswa mulai dari kesulitan sebelum, selama, dan sesudah membaca. Kesulitan di awal, mahasiswa sulit memilih bahan bacaan dan bacaan terlalu tebal sehingga mahasiswa malas membaca. Kesulitan paling banyak adalah selama membaca, sebagian besar mahasiswa tidak memahami kosakata di dalam bacaan. Kalimatnya terlalu panjang dan sulit dipahami. Seorang mahasiswa juga menganggap bacaan terlalu abstrak. Hal ini disebabkan bacaan akademis berbeda dari jenis bacaan lainnya dan panjang dan tingkat teks bervariasi pada berbagai tahap. Teks-teks ini abstrak dan menantang karena mereka memiliki filosofi yang dinyatakan dalam bahasa yang kompleks (Sohail, 2015), yang menyebabkan mahasiswa bosan, dan tidak tertarik membaca lagi. Setelah membaca mahasiswa juga mengalami kesulitan untuk mengambil poin penting dalam bacaan dan cara merangkum bacaannya dengan bahasa sendiri.

\section{Tabel 4. Jenis Bacaan untuk Penugasan}

\begin{tabular}{clcc}
\hline No. & Jenis Bacaan & Jumlah Mahasiswa & Persentase \\
\hline 1 & Buku nonfiksi & 211 & $86,12 \%$ \\
2 & PPT (Materi dari Dosen) & 180 & $73,47 \%$ \\
3 & Artikel Ilmiah & 138 & $56,33 \%$ \\
4 & Berita & 118 & $48,16 \%$ \\
5 & Laporan Penelitian & 107 & $43,67 \%$ \\
6 & Artikel Populer & 95 & $38,78 \%$ \\
7 & Novel & 64 & $26,12 \%$ \\
8 & Cerpen & 63 & $25,71 \%$ \\
9 & Teks Drama & 59 & $24,08 \%$ \\
10 & Puisi & 56 & $22,86 \%$ \\
11 & Skripsi & 44 & $17,96 \%$ \\
12 & Komik & 13 & $5,31 \%$ \\
\hline
\end{tabular}


Tabel 5. Aktivitas Setelah Membaca

\begin{tabular}{clcc}
\hline No. & Aktivitas & Jumlah Mahasiswa & Persentase \\
\hline 1. & Menulis ringkasan/rangkuman & 184 & $74,49 \%$ \\
2. & Menyusun bahan presentasi & 125 & $50,61 \%$ \\
3. & Menceritakan ulang bacaan & 98 & $39,68 \%$ \\
4. & Membuat laporan analisis bacaan & 63 & $25,51 \%$ \\
5. & Menulis resensi & 69 & $27,93 \%$ \\
6. & Membuat laporan buku/bacaan & 49 & $19,84 \%$ \\
7. & Menyunting karangan & 25 & $10,12 \%$ \\
8. & Mengonversi teks & 18 & $7,29 \%$ \\
9. & Menerapkan di kehidupan & 1 & $0,4 \%$ \\
10. & Memberikan penilaian & 1 & $0,4 \%$ \\
11. & Tangkap layar bacaan & 1 & $0,4 \%$ \\
\hline
\end{tabular}

\section{Tabel 6. Kesulitan dalam Membaca}

\begin{tabular}{|c|c|c|c|}
\hline No. & Waktu & Jumlah Mahasiswa & Persentase \\
\hline 1. & Tidak punya bahan bacaan & 116 & $46,96 \%$ \\
\hline 2. & Tidak dapat menyimpulkan isi bacaan & 102 & $41,3 \%$ \\
\hline 3. & Bahan bacaan tidak ada di perpustakaan & 76 & $30,77 \%$ \\
\hline 4. & Malas dan tidak berminat membaca & 19 & $7,69 \%$ \\
\hline 5. & Tidak ada waktu & 11 & $4,45 \%$ \\
\hline 6. & Tidak mengerti cara membacanya & 9 & $3,63 \%$ \\
\hline 7. & Memilih bahan bacaan yang sesuai & 3 & $1,21 \%$ \\
\hline 8. & Sulit memahami kosakata bacaan & 1 & $0,4 \%$ \\
\hline 9. & Memesan buku perlu waktu & 1 & $0,4 \%$ \\
\hline 10. & Tidak paham dengan tugasnya & 1 & $0,4 \%$ \\
\hline 11. & Tidak memiliki kesulitan & 5 & $2,02 \%$ \\
\hline
\end{tabular}

Tabel 7. Kesulitan dalam Membaca Teks Ragam IImiah

\begin{tabular}{clcc}
\hline No. & Kesulitan Mahasiswa & Jumlah Mahasiswa & Persentase \\
\hline 1. & Kosakata tidak dipahami & 142 & $57,49 \%$ \\
2. & Kalimat terlalu panjang dan sulit dipahami & 119 & $48,18 \%$ \\
3. & Tidak tahu poin penting yang bisa diambil & 62 & $25,10 \%$ \\
4. & Tidak dapat memilih bahan bacaan yang sesuai & 38 & $15,39 \%$ \\
5. & Bacaan terlalu tebal & 1 & $0,4 \%$ \\
6. & Malas & 1 & $0,4 \%$ \\
7. & Bosan dan tidak tertarik & 1 & $0,4 \%$ \\
8. & Cara merangkum agar tidak plagiat & 1 & $0,4 \%$ \\
9. & Tidak ada contoh, isi bacaan terlalu abstrak & 1 & $0,4 \%$ \\
10. & Tidak mengalami kesulitan & 1 & $0,4 \%$ \\
\hline
\end{tabular}

\section{Persepsi Dosen terhadap Aktivitas Mahasiswa Setelah Membaca}

Dalam aktivitas membaca yang terstruktur, hasil akhir setelah membaca diperiksa dan dinilai oleh dosen. Ada berbagai tanggapan dosen terhadap kemampuan mahasiswa dalam mengerjakan tugas membacanya. Tanggapan tersebut dijabarkan dalam pernyataan berikut.

\section{a. Kepuasan Dosen terhadap Hasil Tugas Membaca Mahasiswa}

Dari 11 dosen yang memberikan tugas membaca kepada mahasiswa, hanya dua (2) dosen yang menyatakan puas. Jika diPersentasekan sebanyak 18,2\% yang menyatakan puas. Sementara itu, sembilan (9) dosen lainnya atau sebanyak $81,8 \%$ menyatakan kurang puas terhadap hasil yang dikerjakan mahasiswa. 
Alasan yang diberikan untuk tingkat kepuasan tersebut, dijabarkan pada kedua Tabel 8. Berdasarkan Tabel 8 diketahui bahwa kepuasan dosen terhadap hasil membaca mahasiswa mayoritas bertumpu pada kemampuan afektif mahasiswa, seperti sifat "ketelitian" yang tersirat dalam pernyataan "sebagian besar mahasiswa mengerjakan tugas sesuai instruksi"; "kesungguhan" mahasiswa dalam membaca dan mengerjakan tugasnya, dan "kedisiplinan" mahasiswa dalam pernyataan "semua mahasiswa mengerjakan tugas tepat waktu". Selain itu, ada tiga dosen yang menyampaikan bahwa alasan kepuasannya adalah sebagian besar mahasiswa mampu menyimpulkan isi bacaan dengan baik. Namun, ada dua dosen yang tidak memberikan alasan karena memang belum puas terhadap apa yang dikerjakan mahasiswa.

Alasan ketidakpuasan dosen juga ditanyakan dalam angket sebagaimana data pada Tabel 9. Lebih dari $50 \%$ dosen, yaitu $63,63 \%$ atau sebanyak 7 dosen menilai bahwa sebagian besar mahasiswa hanya menyalin ulang isi bacaan. Empat dosen menyampaikan bahwa sebagian besar mahasiswa menyontek. Hal ini bisa disebabkan mahasiswa tidak memahami apa yang dibaca dan ini juga berkaitan dengan pernyataan di nomor 3 bahwa sebagian besar mahasiswa tidak dapat menyimpulkan bahan bacaan. Alasan ini sebenarnya juga tidak lepas dari sifat dasar yang cenderung ingin berpikir mudah, cepat, instan atau berpikir praktis (pernyataan nomor 5). Apalagi generasi digital native, lebih menyukai berpikir praktis dan instan (Ulfah, 2020). Artinya mahasiswa lebih memikirkan "yang penting tugas sudah selesai" tanpa harus memikirkan apa yang diperolehnya setelah membaca.

\section{b. Hambatan Mahasiswa dalam Membaca}

Terakhir adalah pertanyaan tentang kendala mahasiswa dalam membaca menurut dosen dan hasilnya dirangkum dalam Tabel 10. Dari Tabel 10, yang menjadi kendala utama mahasiswa dalam membaca adalah sifat "malas", ini dibuktikan 9 dosen yang memilih dari total 11 dosen. Selanjutnya adalah tidak memiliki pemahaman dan tidak berminat dengan bacaan yang diberikan yang dipilih oleh 5 dosen, ini berhubungan dengan kemampuan mahasiswa, termasuk kemampuan dalam membaca cepat yang berada di urutan ketujuh. Tugas yang terlalu banyak juga menjadi kendala dalam aktivitas membaca mahasiswa. Faktor lainnya berhubungan dengan sarapan dan prasarana, yaitu mahasiswa tidak memiliki bacaan tersebut dan fasilitas serta atmosfer atau suasana perkuliahan yang kurang mendukung.

\section{Tabel 8. Alasan Kepuasan terhadap Hasil Membaca Mahasiswa}

\begin{tabular}{clcc}
\hline No. & \multicolumn{1}{c}{ Alasan Kepuasan } & Jumlah Responden & Persentase \\
\hline 1. & $\begin{array}{l}\text { Sebagian besar mahasiswa mengerjakan tugas sesuai } \\
\text { instruksi. }\end{array}$ & 5 & $45,5 \%$ \\
2. & $\begin{array}{l}\text { Sebagian besar mahasiswa bersungguh-sungguh } \\
\text { dalam membaca dan mengerjakan tugasnya. }\end{array}$ & 3 & $27,3 \%$ \\
3. $\quad \begin{array}{l}\text { Sebagian besar mahasiswa dapat menyimpulkan isi } \\
\text { bacaan dengan baik. }\end{array}$ & 2 & $18,2 \%$ \\
4. $\quad \begin{array}{l}\text { Semua mahasiswa mengerjakan tugas tepat waktu, } \\
\text { tetapi kualitas belum memuaskan. }\end{array}$ & 1 & $9,1 \%$ \\
5. $\quad$ Tidak ada alasan. & 2 & $18,19 \%$ \\
\hline
\end{tabular}


Tabel 9. Alasan Ketidakpuasan terhadap Hasil Membaca Mahasiswa

\begin{tabular}{clcc}
\hline No. & Alasan Ketidakpuasan & Jumlah Responden & Persentase \\
\hline 1. & $\begin{array}{l}\text { Sebagian besar mahasiswa menyalin ulang bacaan } \\
\text { (copy paste). }\end{array}$ & 7 & $63,63 \%$ \\
2. & $\begin{array}{l}\text { Sebagian besar mahasiswa menyontek tugas dari } \\
\text { mahasiswa lainnya. }\end{array}$ & 4 & $36,4 \%$ \\
3. & $\begin{array}{l}\text { Sebagian besar mahasiswa tidak dapat } \\
\text { menyimpulkan bahan bacaan dengan baik. }\end{array}$ & 4 & $36,4 \%$ \\
4. & $\begin{array}{l}\text { Sebagian besar mahasiswa tidak mengerjakan tugas } \\
\text { sesuai instruksi. }\end{array}$ & 1 & $9,1 \%$ \\
5. & Mereka lebih cenderung berpikir praktis. & 1 & $9,1 \%$ \\
6. & Terlalu kaku kurang kreatif. & $9,1 \%$ \\
\hline
\end{tabular}

Tabel 10. Hambatan Mahasiswa Ketika Membaca Mahasiswa

\begin{tabular}{clcc}
\hline No. & Hambatan Mahasiswa & Jumlah Responden & Persentase \\
\hline 1. & Malas & 9 & $81,8 \%$ \\
2. & Tidak memahami bacaan & 5 & $45,5 \%$ \\
3. & Tidak memiliki minat dalam membaca & 5 & $45,5 \%$ \\
4. & Terlalu banyak tugas & 3 & $27,3 \%$ \\
5. & Tidak memiliki bahan bacaan yang diminta & 1 & $9,1 \%$ \\
6. & Fasilitas dan atmosfer belum mendukung & 1 & $9,1 \%$ \\
7. & Kemampuan dalam membaca cepat kurang & 1 & $9,1 \%$ \\
\hline
\end{tabular}

Dari analisis yang sudah dilakukan, ditemukan beberapa hal. Pertama, ada perbedaan jenis bacaan yang sering dibaca mahasiswa ketika membaca mandiri dan terstruktur. Kegiatan membaca mandiri yang artinya membaca hal-hal yang disukai menunjukkan bahwa mahasiswa menyukai bacaan-bacaan nonfiksi seperti novel, puisi, cerpen, bahkan komik. Pembaca dapat merasakan gembira dan kepuasan dari membaca novel, mereka tidak perlu mencemaskan tentang bahasa yang digunakan dalam novel (Tsai, 2012). Tujuan pembacaan nonfiksi untuk kesenangan. Sebaliknya, jenis bacaan yang banyak dibaca oleh mahasiswa dalam kegiatan membaca secara terstruktur adalah bacaan nonfiksi seperti buku referensi, artikel ilmiah, handout (materi ajar) yang merupakan bacaan akademik.

Kedua, mahasiswa memiliki beragam aktivitas setelah membaca, baik secara mandiri maupun secara terstruktur. Aktivitas setelah membaca secara mandiri yang banyak dilakukan mahasiswa seperti mencatat kutipan menarik (quotes), meringkas, mencatat kosakata yang kurang dipahami, atau mendiskusikan dengan teman. Sebuah kutipan akan membantu sebuah bacaan meningkatkan kredibilitasnya karena kata-kata yang baik akan memberi dampak yang besar (Bookmufin, 2017). Ketika mahasiswa rutin dalam mencatat quotes yang dibacanya dapat membantunya lebih bijak dalam situasi apa pun (Communiqué PR Staff, 2011).

Aktivitas setelah membaca yang banyak dilakukan selama perkuliahan adalah menyusun ringkasan, menyusun bahan presentasi, menceritakan ulang bacaan, membuat laporan analisis bacaan, menulis resensi, membuat laporan buku, menyunting karangan, mengonversi teks. Aktivitas di perkuliahan lebih banyak menuntut pemahaman mahasiswa yang disebut kegiatan membaca akademik. Seperti yang dijelaskan Sohail (2015), proses membaca ini adalah proses yang terukur, menantang, dan beragam yang menuntut berbagai strategi 
membaca dalam pelaksanaannya. Namun, sebagai besar mahasiswa menggunakan strategi non-university untuk membaca teks akademik, mahasiswa hanya membaca permukaannya saja (Hermida, 2009). Oleh karena itu muncul beragam kendala mahasiswa dalam mengerjakan tugas membaca, seperti tidak dapat menyimpulkan isi bacaan, tidak memahami kosakata dalam bacaan, dan kalimat yang tidak dipahami. Akhirnya ketika mahasiswa tidak memahami bacaan muncul faktor-faktor lain seperti malas dan enggan membaca. Hal ini juga menjadi jawaban ketidakpuasan dosen terhadap hasil membaca mahasiswa. Ketidakmampuan mahasiswa dalam memahami bacaan menyebabkan mahasiswa cenderung menyalin ulang apa yang ditulis dalam bacaan atau menyontek tulisan temannya. Mahasiswa hanya mengambil ide dari penulis bukan memberikan argumen terhadap apa yang ditulis. Oleh karena itu muncul jawaban ketidakpuasan dosen, yaitu tulisan mahasiswa yang kaku dan kurang kreatif.

Argumen dosen tentang "kemalasan" mahasiswa dalam membaca juga disebabkan faktor ketersediaan bahan bacaan. Ini bisa dilihat dari jawaban mayoritas mahasiswa atas kendala yang dihadapinya untuk mengerjakan tugas membaca adalah bahan bacaan yang tidak tersedia. Bahan bacaan yang tidak tersedia menjadikan mahasiswa mencari jalan pintas untuk menyelesaikan tugas dengan menyontek tugas orang lain. Ketersediaan bacaan memiliki pengaruh terhadap minat baca. Semakin banyak bacaan yang tersedia maka semakin tinggi minat baca, begitu juga sebaliknya (Setyawatira, 2009). Ketika minat baca rendah, muncullah perasaan malas dan enggan untuk membiasakan aktivitas membaca.

Ketiga, dikutip oleh Küçükoğlu (2013), Teele menjelaskan bahwa tujuan semua pembaca harus memahami apa yang mereka baca. Dipertegas oleh Septhin et al., (2018) tujuan utama membaca adalah mencari, memperoleh informasi isi, dan memahami makna bacaan. Pemahaman adalah proses berkembang yang sering dimulai sebelum buku dibuka, berubah saat materi dibaca, dan terus berubah bahkan setelah bacaan selesai (Roe et al., 2019). Namun, jika mahasiswa tidak dapat mengambil poin penting dari bacaan, tidak dapat menyimpulkan, atau hanya menyalin ulang bacaan. Artinya aktivitas setelah membaca yang dilakukan selama perkuliahan belum disadari sepenuhnya sebagai kegiatan untuk memperoleh pengalaman dari apa yang dibaca. Mahasiswa hanya menyelesaikan aktivitas setelah membaca sebagai tuntutan dari perkuliahan. Jika motif membaca dominan untuk memenuhi tuntutan pendidikan maka kebiasaan membaca akan berkurang drastis sesaat setelah menyelesaikan perkuliahan.

\section{Penutup}

Ketika membaca, seorang pembaca yang baik melakukan tiga tahapan, yaitu tahap prabaca (sebelum), selama membaca, dan pascabaca (setelah membaca). Tujuannya untuk membedakan antara apa yang dibawa oleh pembaca saat membaca, apa yang dibawa oleh pembaca saat dia membaca, 
dan apa yang diambilnya dari teks melalui aktivitas membaca yang telah dilakukan. Tahapan ini saling terkait satu sama lain.

Dalam pelaksanaannya, mahasiswa melakukan berbagai aktivitas setelah membaca secara mandiri. Namun, aktivitas tersebut baru sampai pada tahap mengambil informasi dari bacaan belum pada tahap kritis pada sebuah bahan bacaan. Mahasiswa mungkin meringkas secara fisik, namun tidak mental. Kurang dari $25 \%$ tepatnya $23,89 \%$ mahasiswa mendiskusikan apa yang sudah dibacanya, bahkan hanya $0,4 \%$ atau hanya satu orang mahasiswa merenungkan kembali apa yang dibaca, atau melakukan review terhadap bahan bacaan secara mandiri.

Secara kuantitas, tugas terstruktur yang diberikan sebagai aktivitas setelah membaca yang dilakukan mahasiswa begitu beragam. Namun, kuantitas tidak diiringi kualitas dalam memahami bacaan. Mahasiswa mengalami berbagai kesulitan. Ketersediaan bahan bacaan dan ketidakpahaman atas bacaan yang dibacanya membuat mahasiswa tidak maksimal dalam mengerjakan tugasnya. Mahasiswa membaca hanya sekadar membaca, mahasiswa diberikan tugas meringkas setelah membaca namun tidak mampu mengambil poin penting dalam bacaannya. Mahasiswa menyusun laporan bacaan, namun hanya menyalin ulang apa yang ada di bacaan. Untuk menjadi seorang pembaca yang baik, mahasiswa seharusnya mampu merespons, memikirkan, dan merenungkan apa yang dibacanya. Mahasiswa seharusnya tidak memandang bahwa aktivitas membaca hanya sekadar mengetahui simbol-simbol bahasa seharusnya membaca menjadi akses pembaca untuk mentransformasikan pengetahuan dan pengalamannya dengan kreativitas, eksplorasi, dan evaluasi kritis (Wells, 2012).

\section{E. Ucapan Terima Kasih}

Penelitian ini didukung oleh Kementerian Pendidikan, Kebudayaan, Riset, dan Teknologi dan LPDP (Lembaga Pengelola Dana Pendidikan) Kementerian Keuangan. Suatu kehormatan bagi peneliti telah difasilitasi oleh Universitas Pendidikan Indonesia dan Universitas Maritim Raja Ali Haji (UMRAH) dalam melaksanakan penelitian ini.

\section{Daftar Pustaka}

Andina, E. (2017). Strategi Dosen dalam Pengondisian Perilaku Membaca Mahasiswa di Era Digital: Studi Kasus di Kalimantan Barat dan Sulawesi Selatan. Aspirasi: Jurnal Masalah-Masalah Sosial, 8(2), 195-206. https://jurnal.dpr.go.id/index.php/aspirasi/article/view/1265/693

Anjani, R. (2021). Arti AU dan Istilah-istilah Lain yang Dipakai Anak Zaman Now di Twitter. Wolipop. https://wolipop.detik.com/entertainment-news/d5558805/arti-au-dan-istilah-istilah-lain-yang-dipakai-anak-zaman-now-ditwitter

Arcos, E. B. P. (2014). Reading Comprehension among College Students. Journal Sathiri, 8(1), 103-109. https://doi.org/10.1080/00220973.1939.11010153 
Ari, G. (2017). Basic Concepts of Reading Instruction. International Journal of Languages' Education, 1(Volume 5 Issue 4), 484-503. https://doi.org/10.18298/ijlet.2390

Arifin, S. (2020). The Role of Critical Reading to Promote Students' Critical Thinking and Reading Comprehension. Jurnal Pendidikan Dan Pengajaran, 53(3), 318. https://doi.org/10.23887/jpp.v53i3.29210

Bookmufin. (2017). The Importance of Quotations in Literature. https://bookmuffin.wordpress.com/2017/08/06/the-importance-ofquotations-in-literature/

Communiqué PR Staff. (2011). The Importance of Quotes. Communiqué PR. https://www.communiquepr.com/the-importance-of-quotes/2320/

Faizah, D. U., Sufyadi, S., Anggraini, L., Waluyo, Dewayani, S., Muldian, W., \& Roosaria, D. R. (2016). Panduan Gerakan Literasi Sekolah Di Sekolah Dasar. In Journal of Chemical Information and Modeling (Vol. 53, Issue 9). Direktorat Pembinaan Sekolah Dasar.

Freebody, P., \& Luke, A. (1990). Literacies Programs: Debates and Demands in Cultural Context. Prospect: An Australian Journal of TESOL, 5(3), 7-16.

Gibbons, P. (2015). Scaffolding Language, Scaffolding Learning: Teaching English Language Learners in The Mainstream Classroom.

Haapanen, L., \& Perrin, D. (2017). Media and Quoting. In The Routledge Handbook of Language and Media (pp. 424-441). Routledge. https://doi.org/10.4324/9781315673134-31

Hamidon, I. S., Alias, N., Siraj, S., Kokila, K., Mohammed, M., \& Thanabalan, T. V. (2013). Potential of Twitter in Post-reading Activities Among Community College Students in Malaysia. Procedia - Social and Behavioral Sciences, 103, 725-734. https://doi.org/10.1016/j.sbspro.2013.10.393

Han, S. Y., \& Choi, Y. H. (2018). Post-Reading Question-Generation Activities and Cooperative Learning in EFL Reading. English Teaching, 73(2), 37-58. https://doi.org/10.15858/engtea.73.2.201806.37

Handayani, N. N. L. (2019). Determinasi Kegiatan Membaca Mandiri dalam Program Gerakan Literasi Sekolah terhadap Kemampuan Menulis Kreatif Siswa Kelas V Sekolah Dasar. Membangun Budaya Literasi Di Sekolah Dasar.

Hasibuan, J. R. (2015). Planning for Reading: Activities for Before, During, and After Reading. Bahas, 26(1), 62-70.

Herlinyanto. (2019). Membaca Pemahaman dengan Strategi KWL (Pemahaman dan Minat Baca). Deepublish.

Hermida, J. (2009). The Importance of Teaching Academic Reading Skills In First-Year University Courses. The International Journal of Research and Review, 3(September). https://doi.org/10.2139/ssrn.1419247

Hoeft, M. E. (2012). Why University Students Don't Read: What Professors Can Do To Increase Compliance. International Journal for the Scholarship of Teaching and Learning, 6(2). https://doi.org/10.20429/ijsotl.2012.060212

Horne, S. E. (2014). The Effectiveness of Independe. Liberty University.

Huang, S. H., Capps, M., Blacklock, J., \& Garza, M. (2014). Reading Habits of College Students in the United States. Reading Psychology, 35(5), 437-467. 
https://doi.org/10.1080/02702711.2012.739593

Hurst, E. (2011). Academic Literacy Workshops: A Handbook for Students and Instructors. University of Cape Town. https://open.uct.ac.za/bitstream/handle/11427/2400/Academic_Literacy.pdf ?sequence $=1$ \&isAllowed=y

Küçükoğlu, H. (2013). Improving Reading Skills Through Effective Reading Strategies. Procedia - Social and Behavioral Sciences, 70, 709-714. https://doi.org/10.1016/j.sbspro.2013.01.113

Morissan. (2012). Metode Penelitian Survei. Kencana.

Nasehudin, T. S., \& Gozali, N. (2012). Metode Penelitian Kuantitatif. Pustaka Setia.

Nobles-Montanez, L. M. A. G., \& Cruz, R. A. O.-D. (2020). Making Connections: A Metacognitive Teaching Strategy in Enhancing Students' Reading Comprehension. Journal of English Education, 5(1), 49-61. https://doi.org/10.31327/jee.v5i1.1209

Priyatni, E. T., \& Nurhadi. (2017). Membaca dan Literasi Kritis. Tira Smart.

Ratminingsih, N. M. (2017). Metode dan Strategi Pembelajaran Bahasa Inggris. Rajawali Pers.

Rehman, A. U., Khan, K., Almas, A., Mohamad, M., \& Ismail, N. H. (2020). Teachers' Teaching Reading Strategies at Public Elementary Schools in Haripur District. Creative Education, 11(04), 468-478. https://doi.org/10.4236/ce.2020.114034

Roe, B. D., H.Smith, S., \& Kolodziej, N. (2019). Teaching Reading in Today's Elementary Schools.

Sanden, S. (2011). Independent Reading: Perspectives and Practices of Highly Effective Teachers [Washington State University]. In Washington State University. https://doi.org/10.1002/TRTR.01120

Satriani, E. (2018). Reading Comprehension Difficulties Encountered by English Students of Universitas Islam Riau. Journal of English for Academic, 15-26.

Schoenback, R. et al. (1999). Building Comprehension Through Pre- , During- , and Post-Reading Strategies. In Reading for Understanding: A Guide to Improving Reading in Middle and High School Classrooms (pp. 59-76).

Septhin, K., Mulawarman, W. G., \& Suhatmady, B. (2018). Hubungan Minat Baca dengan Kemampuan Menulis Teks Ekposisi Siswa Kelas XI Smk Negeri 9 Samarinda. DIGLOSIA : Jurnal Kajian Bahasa, Sastra, Dan Pengajarannya, 1(2), 89-100. https://doi.org/10.30872/diglosia.v1i2.pp89-100

Setianingsih, T. (2016). Assesment to Improve Reading Comprehension. Journal of English Language, 3(2).

Setyaningtyas, E. W. (2013). Strategi Membaca untuk Mendukung Kebermaknaan dan Keterampilan Literasi untuk Para Pembaca Muda. Aktualisasi Kurikulum 2013 Di Sekolah Dasar Melalui Gerakan Literasi Sekolah Untuk Menyiapkan Generasi Unggul Dan Berbudi Pekeri, 70-77.

Setyawatira, R. (2009). Kondisi Minat Baca Di Indonesia. Jurnal Media Pustakawan, 16(1\&2), 28-33. https://ejournal.perpusnas.go.id/mp/article/view/904/882

Sociality.io. (n.d.). How to Write Engaging Instagram Captions. 
https://sociality.io/files/ebooks/eBook-How-to-write-good-Instagramcaptions.pdf

Sohail, S. (2015). Academic Reading Strategies Used by Leeds Metropolitan University Graduates: A Case Study. Journal of Education and Educational Development, 2(2).

Suwandi, S. (2019). Pendidikan Literasi: Membangun Budaya Belajar, Profesionalisme Pendidik, dan Budaya Kewirausahaan untuk Mewujudkan Marwah Bangsa. PT Remaja Rosdakarya.

Taglieber, L. K. (2000). Critical Reading and Critical Thinking The State of The Art. Ilha Do Desterro A Journal of English Language, Literatures in English and Cultural Studies, O(38), 015-037.

Tsai, C. hsin. (2012). Students' Perceptions of Using a Novel as Main Material in The EFL Reading Course. English Language Teaching, 5(8), 103-112. https://doi.org/10.5539/elt.v5n8p103

Ulfah, M. (2020). Digital Parenting: Bagaimana Orang Tua Melindungi Anak-Anak dari Bahaya Digital. Edu Publisher.

Wahjudi, A. (2010). Interactive Post-reading Activities that Work. Jurnal Bahasa, Sastra, Seni, Dan Pengajarannya, 38(1), 84-92.

Wahyono, E., \& Puspitasari, D. (2016). Students' Need Analysis of English Reading Skills for Academic Purposes. Prosiding Ictte, 1(1), 1007-1014.

Waspada. (2021). Rendah, Rasio Ketersediaan Buku dan Jumlah Penduduk Indonesia. Waspada.Id. https://waspada.id/pendidikan/rendah-rasioketersediaan-buku-dan-jumlah-penduduk-indonesia/

Wells, C. (2012). Aliterate College Students: A Neglect Of Reading Or A New Type Of Literacy? In Stars (Issue 2012). University of Central Florida.

Widoyoko, E. P. (2012). Teknik Penyusunan Instrumen Penelitian. Pustaka Pelajar.

World Bank. (2018). Pendidikan untuk pertumbuhan. Indonesia Economic Quarterly, 83. 